\title{
PHONEMIC AWARENESS IN AN ORAL GERMAN-ORIGIN BRAZILIAN LANGUAGE: A STUDY OF HUNSRÜCKISCH AND GERMAN BILINGUALS
}

\author{
Bernardo K. Limberger ${ }^{*}$ \\ ${ }^{1}$ Universidade Federal de Pelotas, Pelotas, RS, Brasil \\ Aline Fay de Azevedo ${ }^{2 * *}$ \\ Evelyn C. Ferstl ${ }^{3 * * *}$
}

${ }^{2}$ Pontifícia Universidade Católica do Rio Grande do Sul, Porto Alegre, RS, Brasil

${ }^{3}$ Albert-Ludwigs-Universität Freiburg, Center for Cognitive Science, Freiburg, Germany

\begin{abstract}
Augusto Buchweitz ${ }^{2 * * * *}$
${ }^{2}$ Pontifícia Universidade Católica do Rio Grande do Sul, Escola de Ciências da Saúde, Porto Alegre, RS, Brasil
\end{abstract}

\begin{abstract}
Phonemic awareness is the ability to notice and manipulate language sounds in their base form (phonemes). It is associated with emerging literacy skills and predictive of skilled reading. The aim of the present study was to investigate phonemic awareness in German and its association with speaking a German-origin, but predominantly unwritten language. We investigated speakers of Hunsrückisch, a Brazilian minority language predominantly used in its spoken form. Participants were literate Brazilian Portuguese speakers who spoke Hunsrückisch and German or Hunsrückisch only. The results show faster, more accurate performance in the phonemic awareness task among participants who spoke Hunsrückisch and German, relative to those who spoke Hunsrückisch only. Participants who spoke Hunsrückisch only were able to perform the phonemic awareness tasks, but having learned to read and write in German allowed for faster, more accurate performance, especially in relation to pseudowords.

Keywords: Phonemic Awareness; Reading; Writing; Multilingualism; Hunsrückisch.
\end{abstract}

\footnotetext{
${ }^{*} \mathrm{PhD}$ in Language Studies (Pontifical University of Rio Grande do Sul - PUCRS). Adjunct Professor at the Federal University of Pelotas (UFPEL), Graduate Program of Language Studies, Pelotas, Brazil. His e-mail address is: limberger.bernardo@gmail.com. ORCID: http://orcid.org/0000-0001-5504-2361

${ }^{* *} \mathrm{PhD}$ in Language Studies (PUCRS). Professor at the School of Humanities, PUCRS, Porto Alegre, Brazil. Her e-mail address is: alinefay@gmail.com. ORCID: http://orcid.org/0000-0002-7180-903X

${ }^{* * *} \mathrm{PhD}$ in Cognitive Psychology (University of Colorado, Boulder, USA). Professor at the Center for Cognitive Science, Albert-Ludwigs-Universität Freiburg, Germany. Her e-mail address is: evelyn.ferstl@cognition.unifreiburg.de. ORCID: http://orcid.org/0000-0001-8335-1276

${ }^{* * * *} \mathrm{PhD}$ in English Linguistics (Federal University of Santa Catarina). Professor at the School of Health Sciences, PUCRS, Porto Alegre, Brazil. His e-mail address is: augusto.buchweitz@pucrs.br. ORCID: http://orcid. org/0000-0003-3791-7472
} 
The present study investigated phonemic awareness among speakers of Hunsrückisch, a German-origin, (mostly) unwritten language spoken in Brazil. Hunsrückisch is mostly used in informal settings (Altenhofen et al., 2007). It is a dialectal continuum formed by dialects brought by German immigrants (Altenhofen, 1996) and it does not have a standardized writing system. However, there are already writing rules of Hunsrückisch based on Standard German spelling (cf. Altenhofen et al., 2007).

Hunsrückisch has been the focus of sociolinguistic studies (Altenhofen, 1996; Altenhofen et al., 2007; Gewehr-Borella, 2014; Machado, 2016; SambaquyWallner, 1998; Schaumloeffel, 2003; Schneider, 2007; Wiesemann, 2008) and of a handful of psycholinguistic studies of bilingualism/multilingualism and cognition (Billig, 2014; Kramer \& Mota, 2015; Limberger, 2018; Limberger $\&$ Buchweitz, 2014). Few studies have investigated reading-related processes, i.e. the impact of the oral language on decoding, literacy and phonological awareness of speakers of minority linguistic varieties. Examples include studies of Tyrolean in Italy, African-American English in the United States and Puxian and Minnan in China (Abutalebi et al., 2007; Brown et al., 2015; Chen, Li, Li, Wang, \& Wu, 2013).

Phonemic awareness is one of the core skills associated with learning to read. It involves the ability to identify and manipulate word sounds, and it is a predictor of reading success (Castles, Rastle, \& Nation, 2018; Castro-Caldas, Petersson, Reis, \& Stone-Elander, 1998; Morais, Cary, Alegria, \& Bertelson, 1979; Reis \& Castro-Caldas, 1997). Studies with illiterate adults showed that they have a hard time performing tasks that require phoneme analyses, such as deletion and addition of phonemes in pseudowords (Morais et al., 1979). Reis and CastroCaldas (1997) and Castro-Caldas et al. (1998) showed that illiterate adults have difficulties repeating pseudowords out loud.

According to Ziegler \& Goswmi (2005), phonemic awareness covers the ability to recognize, identify and manipulate any phonological unit within a word, such as a phoneme (G-R-A-S-P), a syllabic onset (G-RASP), a rhyme (GRA$\mathrm{SP}$ ) or one syllable (GRASP). To assess this level of awareness, researchers have conducted experiments with phonemes, syllables or words. Tasks with explicitly presented stimuli are relatively easy because only sensitivity is needed to perceive similarities between words (Fricke \& Schäfer, 2011). These recognition tasks involve, for example, phoneme identification tasks (do two words start with the same sound?). On the other hand, tasks of phonemes synthesis and manipulation are more difficult because they require a more conscious confrontation with the word form, which is not always necessary for the actual use of languages (Fricke \& Schäfer, 2011). In synthesis tasks, the participant needs to join phonemes or syllable structures to form words. In manipulation tasks, the participant recognizes units but must subdivide or modify them by deleting, inserting, or substituting some phoneme. Manipulating words with consonant clusters is even more difficult in comparison to words without them (Arnqvist, 1992). Onset or rhyme are often perceived as cohesive items, making it difficult to perceive 
individual phonemes. These experiments aim to assess phonemic awareness, which is crucial in learning to read, as discussed below.

\section{Phonemic awareness and oral languages}

Hunsrückisch does not have an orthography of its own (Altenhofen et al., 2007), but it is a variety of the German language. In the present study, we asked whether speaking a mostly unwritten language transfers literacy skills to manipulating sounds in an associated, written variety, in this case, Standard German. The transfer of phonemic awareness has been demonstrated among languages with different origins and orthographies, such as English and Spanish (Durgunoğlu, Nagy, \& Hancin-Bhatt, 1993). Phonological awareness in one language was associated with better reading in the other. It has been postulated that transfer of phonemic awareness is hindered by the grapheme-phoneme association idiosyncrasies of each language (Reynolds, 1998). Transfer of phonemic awareness may be associated with language similarities in their grapheme and phonemes associations, e.g. the awareness of Hunsrückisch consonant clusters [st] and [sp] and other specific phonological units of Germanic languages such as the long vowels can be transferred to German, when Hunsrückisch speakers learn German.

There are language-related differences in phonological units, from phonemes to syllables (Ziegler \& Goswami, 2005). Languages vary in terms of their orthographic consistency, which represents the level of correspondence between orthographic units and phonological units. Orthographic systems vary with respect to the regularity of these correspondences (Frost, Katz, \& Bentin, 1986; Seymour, Aro, \& Erskine, 2003). In regular (shallow) orthographies, each phoneme is nearly unequivocally represented by one grapheme. Finnish, Greek, Italian and Spanish have regular orthographies (Seymour et al., 2003). Languages such as Norwegian, Icelandic and German also have transparent orthographies. German orthography is mostly organized in a one-to-one association with its phonemes (Duden, 2005). In irregular (deep) orthographies, such as French, English and Danish, more than one grapheme may map onto phonemes, and vice-versa. There is, thus, variability in the grapheme-phoneme correspondence (Landerl et al., 2013; Landerl, Wimmer, \& Frith, 1997; Seymour et al., 2003).

Studies of transfer in language skills have focused on the effects among children. To our knowledge, no studies have investigated transfer of phonemic awareness associated with a minority, mostly unwritten dialect in literate adult bilinguals. Brown et al. (2015) showed that the differences between English spoken by African Americans and Standard English were associated with difficulty learning to read. Chen et al. (2013) evaluated the phonological awareness of dialect speakers with judgment of onset, rhyme, syllable and tone awareness. Monolingual speakers were compared with bilingual (Mandarin and one dialect) and multilingual (Mandarin and two dialects) children. The study showed superior performance for monolingual children relative to bilingual/multilingual children of the same age group; the advantage of monolingual children disappeared as 
older children were investigated. The results suggest that the dialect experience may delay the development of phonological awareness in Mandarin. According to the authors, inferior Mandarin phonological awareness could be related to the circumstantial Mandarin use. Delays associated with growing up bilingual have also been identified in vocabulary and naming, for example (Gollan, Montoya, Fennema-Notestine, \& Morris, 2005; Sullivan, Poarch, \& Bialystok, 2017). The developmental issue of growing up bilingual is beyond the scope of the present paper; but delays in vocabulary and naming, for example, can influence, but do not compromise the development of reading skills (Koda, 2007).

In this study, we investigated phonemic awareness in German and its association with speaking Hunsrückisch, a German-origin, but predominantly unwritten language. Three language groups took part in the study: Multilinguals (Portuguese, German and Hunsrückisch speakers), Hunsrückisch bilinguals (Portuguese and Hunsrückisch speakers), and German Bilinguals (Portuguese and German speakers). They performed a phonemic awareness task, composed of two tests. Only German speakers have schooling in German writing, and thus, their results are expected to be fundamentally different from the Hunsrückisch only speakers. The hypothesis of the study is that phonemic awareness is developed while individuals learn to read in a specific language (cf. Castro-Caldas et al., 1999; Morais, Cary, Alegria, \& Bertelson, 1979).

\section{Method}

\section{Participants}

Adult participants were initially recruited, for convenience, in the metropolitan area of Porto Alegre, Brazil. The initial application of the criteria (adult, neurobiological and ophthalmologic healthy, and highly schooled participants) and the search for participants resulted in a sample of 91 adult multilinguals, Portuguese speakers, who were literate in this language, mostly multilingual. After language group-specific criteria were applied, 85 participants remained. Participants were given information about all stages of the study and signed an informed consent form. The study was approved by the Research Ethics Committee at the Pontifical Catholic University of Rio Grande do Sul (PUCRS), Brazil, (CAAE: 53895416.4.0000.5336).

Participants were divided into three groups according to their language background, assessed with the Language Background questionnaire for research with bilinguals (Scholl \& Finger, 2013): Multilinguals (Portuguese, German and Hunsrückisch: $n=28$ ), Hunsrückisch bilinguals (Portuguese and Hunsrückisch: $\mathrm{n}=29$ ), and German Bilinguals (Portuguese and German: $\mathrm{n}=28$ ). The Multilingual and the Hunsrückisch groups included speakers who acquired Hunsrückisch and Brazilian Portuguese simultaneously, since childhood. The Multilinguals also spoke German, which was taught in formal settings, including reading and writing. The German group was composed by bilinguals who spoke 
Portuguese and German and did not have contact with any minority language, i.e. an oral language without official status. Some participants also spoke an additional majority language, mainly English or Spanish. Speaking a third, or fourth language was not factored in the analyses. The general description of group demographics is shown in Table 1.

Table 1: Participant demographics.

\begin{tabular}{llll}
\hline & Multilinguals & Hunsrückish & German \\
\hline Mean age: years (SD) & $27.8(6.9)$ & $29.9(6.1)$ & $24.5(6.0)$ \\
Age range: years & $18-43$ & $18-45$ & $18-39$ \\
Sex: F/M & $23 / 5$ & $23 / 6$ & $22 / 6$ \\
Schooling: years (SD) & $15.8(2.4)$ & $17.9(2.3)$ & $15.9(3.7)$ \\
$\begin{array}{l}\text { Age of acquisition of German } \\
\text { (SD) }\end{array}$ & $12.8(6.1)$ & - & $10.7(4.6)$ \\
\hline
\end{tabular}

$\mathrm{SD}=$ standard deviation

Participants were young and middle-aged adults. They had college education or were college students and had a normal or corrected vision. Participants had neither hearing problems nor learning disorders. Speakers of Hunsrückisch resided in regions in which the Deitsch variety is spoken (Altenhofen, 2010; Machado, 2016).

\section{Instruments}

\section{Phonemic Awareness}

We selected nouns in German and Hunsrückisch (cognates and noncognates), and pseudowords for the experiment. There are 24 words in each condition, divided into the two phonemic tests. We tested phoneme synthesis and syllabic onset manipulation. These tests were based on the test battery of German phonological awareness (Fricke \& Schäfer, 2011).

The stimuli were selected from an initial set of 96 words. We excluded German nouns that were phonologically distant from the words in Hunsrückisch. We used the Levenshtein Distance to assess the phonological differences between each pair of cognate words (Heeringa, 2004; Möller, 2011). This distance was calculated using an algorithm in R (R Core Team, 2013). Words in German were phonetically transcribed according to Duden (2010), and words in Hunsrückisch, according to Altenhofen (1996), who uses German spelling rules. The final stimulus set included 24 words, 12 for each test of phonemic awareness. We excluded words whose distance was greater than 0.5 (on a scale ranging from 0 to 1.0); the final set of pairs of words had an average distance of 0.34 , (SD 0.16). Word frequency was established using the SUBTLEX-DE database (Brysbaert et al., 2011). We excluded words whose frequency was less than 2/1 million (Gordon, 1983). Since Hunsrückisch does not have a corpora of words, 
we replaced frequency measures with a familiarity test (on a scale ranging from 1 to 5) and selected words based on speakers' opinions about the frequency of word use. Sixty speakers of Hunsrückisch from the Deitsch region were asked if they used the words in Hunsrückisch conversation. We selected words that had scores above the mean (4.2 points). Five words were excluded, and the remaining words were analyzed for number of phonemes, Levenshtein distance (in this case, words more phonologically distant from words in German), number of syllables, syllable structure, number of consonant clusters and diversity of German phonemes.

The phoneme synthesis test involved the presentation of isolated sounds, in sequence. Participants had to identify whether successively presented sounds formed the written word presented on the screen. The syllable onset manipulation test involved manipulation of syllable onset (see experimental Paradigm). The stimuli were distributed in 3, 4, 5 or 6 sounds. We included words with different articulation points and manners, which reflect the transparency of the German-specific grapheme-phoneme conversion rules (cf. Altenhofen et al., 2007). Word selection was based on dialectological studies (Altenhofen, 1996; Altenhofen et al., 2007; Machado, 2016; Sambaquy-Wallner, 1998; Schaumloeffel, 2003; Wiesemann, 2008), which document Hunsrückisch in the Deitsch region in Brazil. German words were German-Hunsrückisch cognates, pairs of words which share etymology and thus semantic and phonological features, e.g. 'Jacke' ['jakə] and ['jagə]. The goal was to investigate phonemic awareness in words that were used in both languages.

Pseudowords were generated using the Wuggy software (Keuleers \& Brysbaert, 2010). Words in German and Hunsrückisch were used as a basis to create pseudowords. Seven German-based, seven Hunsrückisch-based and eleven pseudowords that could belong to either language (phonological overlap for the entire word) were generated. Selected words had one to three syllables, which included 2 to 5 phonemes. In the syllable onset manipulation test, there was a comparable number of consonant clusters to be dismembered across languages (for example, ['Jb]esje, ['br]unnen and [' $[\mathrm{m}] \mathrm{ekle}$ ). The descriptive data for the three types of stimuli, each set composed by 24 words, are described in Table 2 (for the stimuli list, see Appendix; for details, see Limberger, 2018). We carried out a unifactorial ANOVA to investigate differences between the stimuli: there were no statistically significant differences for any of the criteria.

Table 2: Phonemic Awareness Task: indices and characteristics of the stimuli.

\begin{tabular}{llll}
\hline & Cognates & Hunsrückisch & Pseudowords \\
\hline Length in letters (SD) & $5.46(1.67)$ & $5.88(1.03)$ & $5.58(1.44)$ \\
${\text { Syllables }(S D)^{1}}^{1}$ & $1.58(0.57)$ & $1.54(0.50)$ & $1.50(0.5)$ \\
Phonemes per syllable $^{2}$ & 2 to 5 & 2 to 5 & 2 to 5 \\
Consonant clusters (SD) & $0.58(0.49)$ & $0.62(0.63)$ & $0.62(0.70)$ \\
Phonological distance between cognate pairs ${ }^{3}(\mathrm{SD})$ & $0.34(0.16)$ & $0.75(0.15)$ & -- \\
Estimated orthographic distance between cognate pairs $^{3}$ & $0.12(0.14)$ & $0.58(0.20)$ & --
\end{tabular}




\begin{tabular}{llll} 
Duration - Phoneme synthesis test - ms (SD) & $4828(1212)$ & $4438(1440)$ & $4886(1343)$ \\
Duration - test $2 \mathrm{~ms}(\mathrm{SD})$ & $1526(294)$ & $1526(161)$ & $1628(213)$ \\
\hline
\end{tabular}

$1=$ Average; 2 = Range; 3 = Levenshtein Distance; $\mathrm{ms}=$ milliseconds; $\mathrm{SD}=$ Standard Deviation

The stimuli were recorded by two native female speakers of each language. Both had knowledge of phonetic transcription of German and good pronunciation skills. They were directed to produce the words as naturally as possible, avoiding any prosodic cues and following the phonetic transcription. The isolated sounds produced for the phoneme synthesis task were recorded using a Roland R-09HR high-resolution (24bit / 96kHz) recorder with an integrated microphone. Audios were adjusted for uniformity according to the procedures described in Machry da Silva (2014), and using Audacity and the Praat software (Boersma, 2001, version 6.0.28). First, noise was removed, and next the speaker's voice intensity was normalized to $50 \mathrm{db}$ for all stimuli. We standardized the intervals between the phonemes of words from 400 to $550 \mathrm{~ms}$. Figure 1 shows a spectrogram with an example of stimulus in phoneme synthesis test.

Figure 1: Spectrogram of stimulus [fee $\int \mathrm{d}$ ]]. Praat software (Boersma, 2001). The dashed circle highlights the final devoicing in Hunsrückisch.

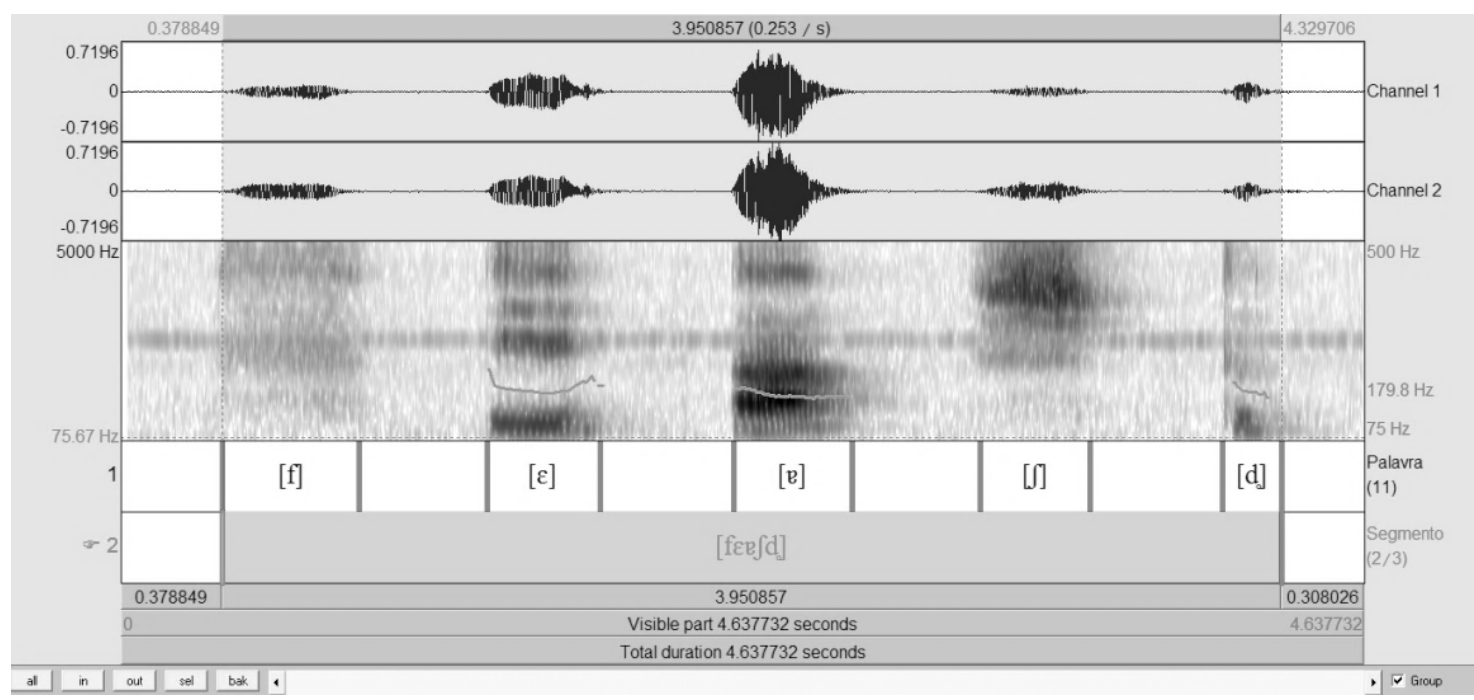

The spectrogram in Figure 1 shows the uniform pauses between the phonemes and the voicing and devoicing of consonants; the final devoicing is an idiosyncrasy of Hunsrückisch (see the dashed circle in the figure). The acoustic analysis of consonants showed that there was a variation in sonority; for example, the voiceless stops of Hunsrückisch [b], [d] and [g̊] were not always produced as such. The variation is associated with the support of vowel or aspiration. Hunsrückisch has variation in sonority (Altenhofen, 1996; Gewehr-Borella, 2014) and participants recognized the sounds in the pilot study in Germany. Therefore, oral productions with variation in sonority were kept in the study. The vowels were acoustically analyzed following the F1 and F2 formants of the cardinal vowel's parameters 
(Catford, 1977). Acoustic analyses showed that vowels occupied acoustic spaces like those occupied by cardinal vowels. We considered that the speakers' vocalic productions are in harmony with the phonetic symbols of the proposed words.

\section{Experimental Paradigm}

The task was divided into two tests (Figure 2), administered one after the other, always in the same order for all participants. The instruction for the two tests appeared on the computer screen, in white Arial font (size 18) over a black background. The words and anchor points were also presented in this format.

Participants were instructed to listen to the words and then press the space bar. Next, a word appeared on the screen and participants were instructed to answer the following question in relation to the word they had heard: "Could the word you heard be written like this?" YES or NO. Participants were instructed to strike the S key (green-labeled) on the computer keyboard for YES, and the L key (red-labeled) for NO. Each stimulus was presented once. In each test, 12 words in each condition were presented sequentially, and the order of yes- and no-trials was random. The no-trials were set up by modifying a letter. Prior to the experimental paradigm, participants practiced using a six-word training set for each of the tests.

Figure 2: Illustration of the Phonemic Awareness Task. From left to right: Participants listened to the stimuli; 500-ms pause; target stimuli presented visually.

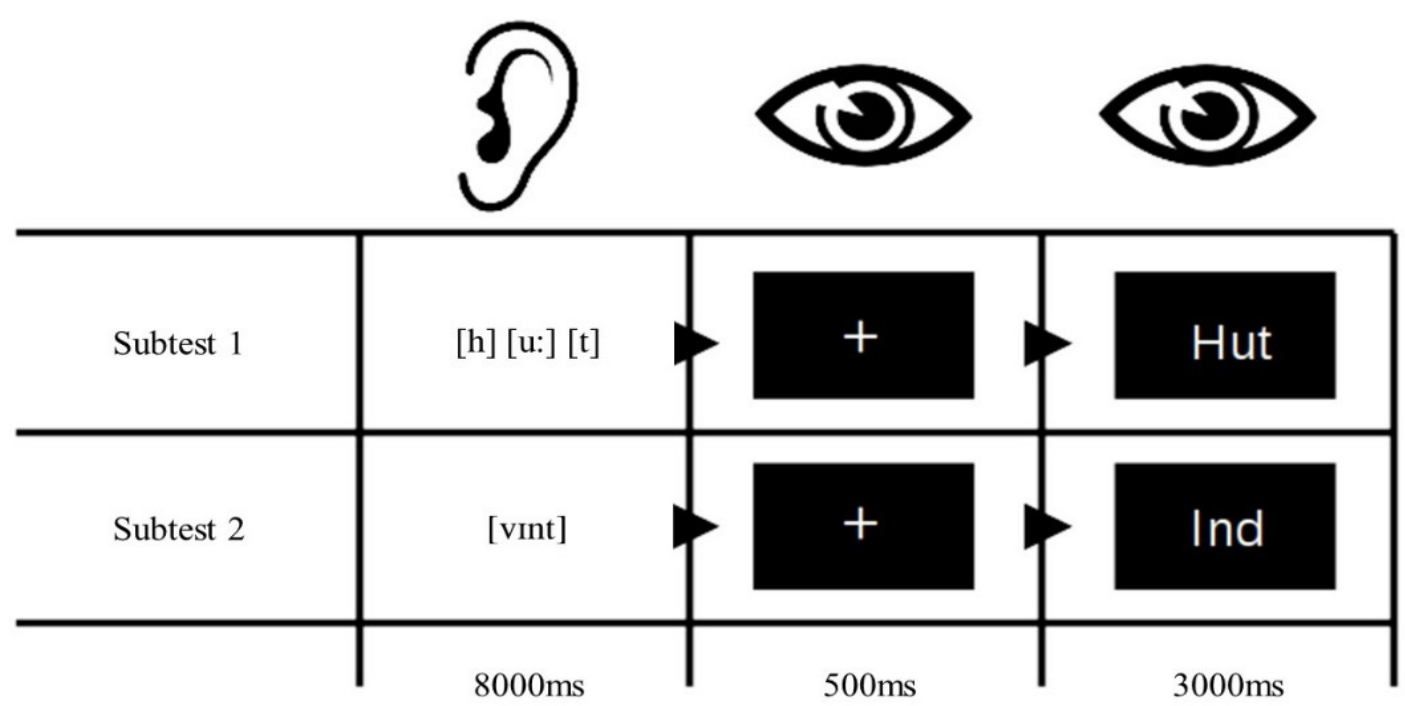

In the phoneme synthesis test, participants listened to sounds such as [h] [u:] [t] and were instructed to mentally combine the phonemes. Next, a word appeared on the screen. If the graphemes presented corresponded to the phonemes they heard, they were instructed to press YES (green key); if not, NO (red key). After the presentation of each stimulus, a fixation mark was displayed for $500 \mathrm{~ms}$ on the computer screen. The complexity of the word combinations increased 
gradually, from words with three phonemes up to six phonemes at the end of the experiment. Three versions of the task were programmed (with varying orders of presentation conditions, but increase in complexity was maintained), and these versions were counterbalanced across the participants. The task was presented using PsychoPy, version 1.85.2 (Peirce, 2009).

In the syllable onset manipulation test, participants were asked to suppress the first phoneme of a syllable. They heard, for example, the word 'Wind' [vint] and had to mentally generate [int]. Next, a word appeared on the screen. Again, participants were asked to check whether the graphemes presented corresponded to the result of the syllable manipulation.

\section{Procedure}

Before the experiment started, the entire procedure was explained to the participant based on the information contained in the informed consent form. Subsequently, participants filled out a demographic questionnaire (Scholl \& Finger, 2013). We used an HP Pavilion 14' notebook and a headset for the experiments. The location of the data collection varied according to the participants' desire and availability, as long as the environment was well lit and quiet. Data collection was carried out at libraries, schools, city halls and in family homes.

\section{Data Analysis}

Statistical analyses were carried out using SPSS ${ }^{\circledast}$ software 19.0 (IBM Corp., 2010). The dependent variables were response time (RT) and accuracy. We used Kruskal-Wallis non-parametric test for the analysis of accuracy (data were not normally distributed). The reaction time data were analyzed using $3 \times 3-$ ANOVAs with the factors word type (German, Hunsrückisch, pseudoword) and language group (Multilinguals, Hunsrückisch bilinguals, and German Bilinguals). Omitted or wrong answers were not included in the RT-analyses. Group comparison involved analyses the main effects and interactions of the variable "word type" (word in Hunsrückisch, word in German and pseudoword) in each of the tests. We adopted a significance level of $p<0.05$ for all tests. A unifactorial ANOVA with Bonferroni post-hoc tests for each condition separately was conducted to compare the RT means of the groups for the three conditions: Hunsrückisch, German and pseudowords.

\section{Results}

\section{Phoneme synthesis test}

In the Phoneme synthesis test, there were no differences between the groups in accuracy (Fig. 3). This suggests comparable proficiency, though cognitive processing may have varied (response times) (Fig. 4). 
Figure 3: Accuracy in Phonemic Awareness Task (Phoneme synthesis test). MULTI = multilingual Hunsrückisch and German (black bars), HUNS = bilingual Hunsrückisch only (gray bars), GER = bilingual German only (white bars).

Accuracy (percentage) - Phoneme synthesis test

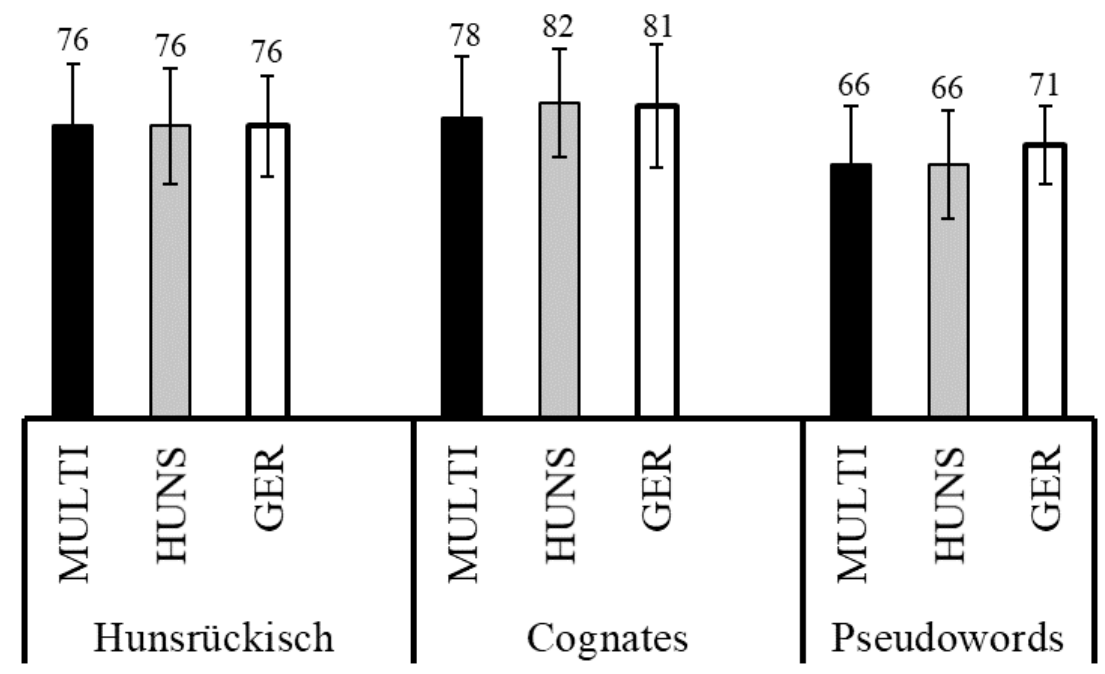

The results of response times in phoneme synthesis task show that the three groups differed $[F(2,82)=3.48, p=0.003]$. The results show also a main effect of word type $[F(2,82)=12,821, \mathrm{p} \leq 0.001]$ for response time.

Figure 4; Response times in Phonemic Awareness task (Phoneme synthesis test). MULTI = multilingual Hunsrückisch and German (black bars), HUNS = bilingual Hunsrückisch only (gray bars), GER = bilingual German only (white bars). Significant differences are indicated by ${ }^{\star} \mathrm{p}<0.05$.

Response Times (ms) - Phoneme synthesis test

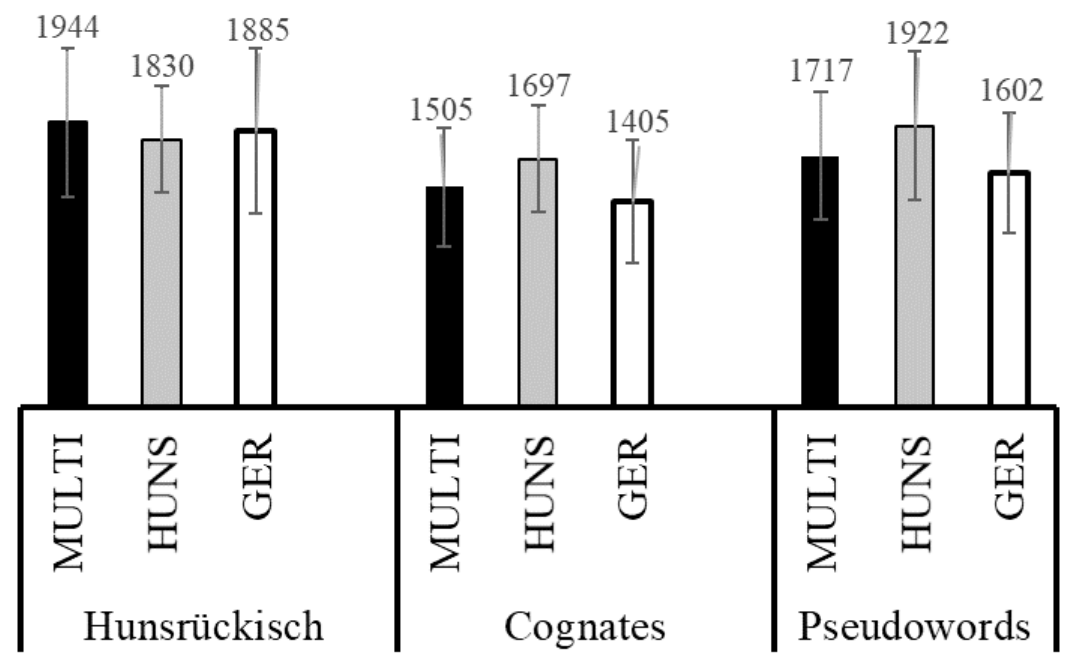


Post-hoc Bonferroni tests indicated significant differences in the phoneme synthesis of the cognate words between the HUNS and GER group $(p=0.018)$ and of the pseudowords between the HUNS and the GER group $(p=0.027)$.

\section{Syllable onset manipulation task}

In syllable onset manipulation task, there were a significant effect of group $\left[\mathrm{X}^{2}(2)=9.75, p=0.008\right]$. MULTI was more accurate in the words in the cognates condition than in the words in Hunsrückisch $(p=0.027)$, and the GER group had higher accuracy scores in the condition Cognate words compared to pseudowords $(p=0.011)$.

Figure 5: Accuracy in Phonemic Awareness Task (Syllable onset manipulation test). MULTI = multilingual Hunsrückisch and German (black bars), HUNS = bilingual Hunsrückisch only (gray bars), GER = bilingual German only (white bars). Significant differences are indicated by ${ }^{* *} \mathrm{p}<0.01$.

Accuracy (percentage) - Syllable onset manipulation test

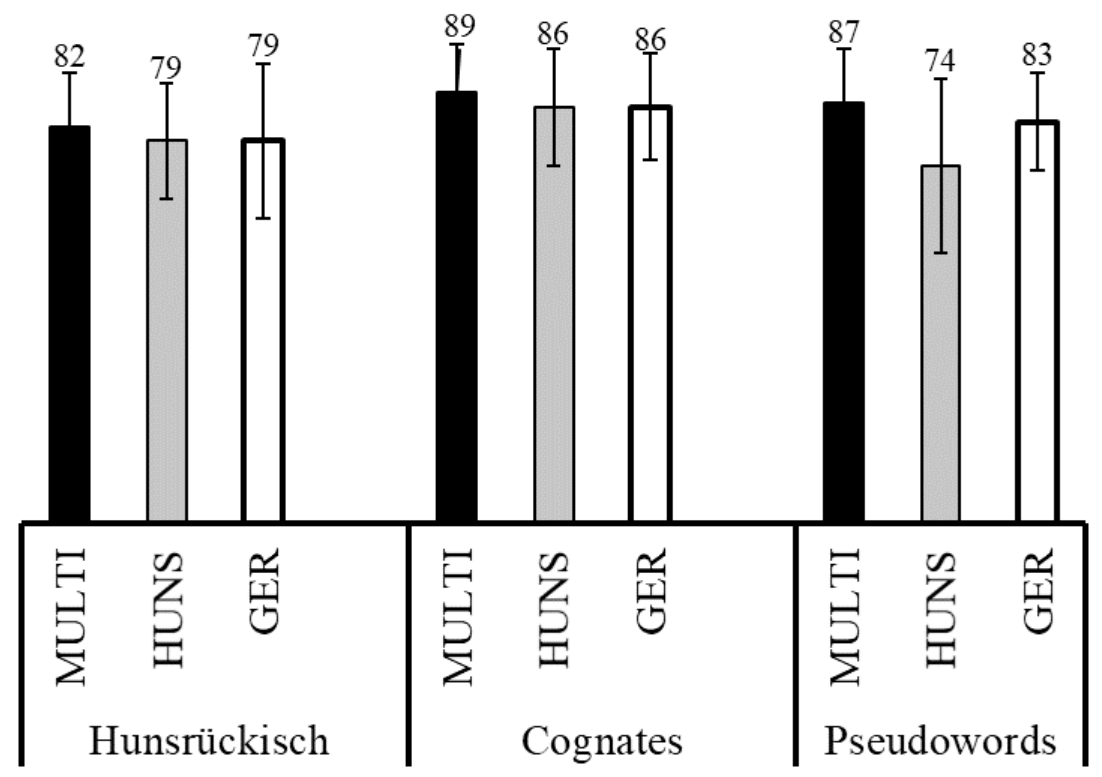

The results of response times in Syllable onset manipulation task show an effect of group $[F(2,80)=5.47, p=0.005]$. The results show also a main effect of word type $[F(2,80)=7.721, \mathrm{p}=0.001]$ for response time. The interaction between word and group was not significant.

Post-hoc Bonferroni tests indicated differences were significant for the Cognates condition between the MULTI group and the HUNS group $(p=0.011)$. In general, the results suggest pseudowords presented the most difficulty to Hunsrückisch bilinguals. 
Figure 6: Response in Phonemic Awareness Task (Syllable onset manipulation test). MULTI = multilingual Hunsrückisch and German (black bars), HUNS = bilingual Hunsrückisch only (gray bars), GER = bilingual German only (white bars). Significant differences are indicated by ${ }^{*} \mathrm{p}<0.05$.

Response Times (ms) - Syllable onset manipulation task

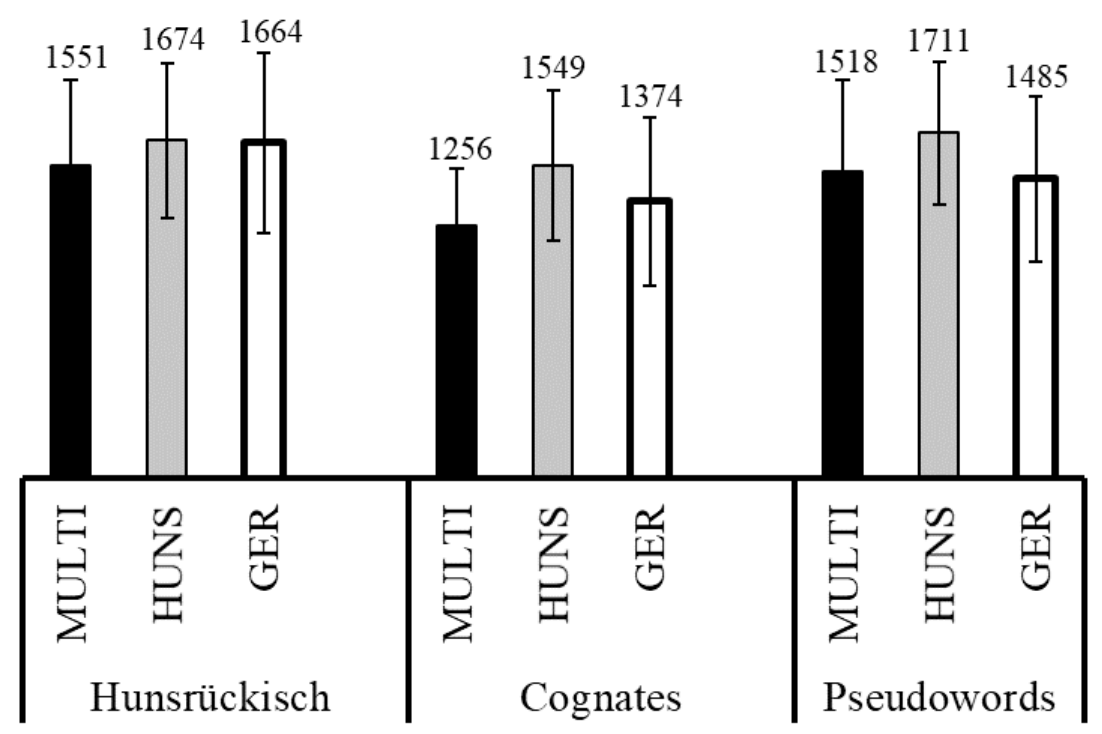

The syllable onset manipulation task showed significant differences in accuracies across all groups. Participants in the MULTI group were more accurate in words in Hunsrückisch compared to pseudowords $(p=0.033)$ and in cognate words (condition Cognates) compared to pseudowords $(p=0.011)$. Participants of the HUNS group were more accurate in the condition Cognates compared to pseudowords $(p<0.001)$, and the GA group on comparing pseudowords to words in Hunsrückisch $(p=0.020)$.

The results of both phonemic awareness tests indicate superior performance of all groups in both reaction time and accuracy with cognate words, that is, German word processing in comparison to words in Hunsrückisch and to pseudowords.

\section{Discussion}

The results suggest that performance in phonemic awareness for words in German was different among adults who were literate in German than adults who learned a dialectal, unwritten form of German origin. Our results show that bilingual speakers of Hunsrückisch were slower in phonemic awareness tasks. These results suggest that the ultimate development of phonemic awareness is associated with literacy in the specific language. Pseudowords presented the greatest challenge to Hunsrückisch bilinguals. The ability to process pseudowords and to manipulate them is strongly associated with learning to read (Morais, 1995, 2009). In both tests, the MULTI and the GER group had similar responses, 
because they had knowledge of German spelling. However, in the GER group, the differences occurred more frequently compared to the words in Hunsrückisch, also interpreted as pseudowords. The ability to perform the tests above chance level suggests some level of literacy development among Hunsrückisch bilinguals.

Hunsrückisch bilinguals, relative to themselves, had more difficulty with pseudowords than words in Hunsrückisch. Though the Hunsrückisch group is not literate in German, contact with the written form of surnames (Stein, Schneider, Müller, Limberger, Buchweitz, among many others), localities (Loch, for example, is part of Teufelsloch 'Devil's Hole', in Ivoti, Rio Grande do Sul, Brazil) among others (Altenhofen et al., 2007; Machado, 2016) may aid in the development of literacy in German. The contact with German writing is not entirely absent, and the performance in the phonemic awareness task is not so good relative to German bilinguals, but Hunsrückisch bilinguals were able to achieve comparable accuracy in some of the tests. Therefore, they can also rely on German spelling besides being literate in Portuguese.

We predicted that participants in the HUNS group would be slower and less accurate in processing German words, including Hunsrückisch cognates. Though relatively accurate, slower response time for Hunsrückisch bilinguals relative to German bilinguals suggests the advantages of learning to read and write in the language. Our results indicate that, ultimately, phonemic awareness depends on learning to read and write in the language (Castro-Caldas et al., 1999; Morais et al., 1979), and though some level of accuracy is attained with an oral language, processing is significantly slower relative to German bilinguals and Multilinguals. These differences suggest that the Hunsrückisch bilinguals may recognize German words, but they rely on some spelling knowledge and on Portuguese spelling rules. Therefore, for this group, the ability to relate graphemes and phonemes in German exists but is not as automatized as for the other groups.

The lack of corpora in Hunsrückisch was a challenge for the experimental design. We prospected dialectological studies to catalog cognate and noncognate candidates in the experiment. The stimuli were verified by Hunsrückisch speakers. Moreover, in the phoneme synthesis test, the isolated productions of stop consonants, whose release depends on a supporting or intrusive vowel, was not always ideal. This production was evaluated before the experiment; in the pilot study, participants could recognize the words.

Future studies should try to test phonemic awareness using only oral stimuli, although this kind of awareness is closely related to literacy (Castro-Caldas et al., 1999; Dehaene, 2012; Morais et al., 1979). It is possible that despite showing good phonemic awareness, participants still have a hard time reading letter strings.

For learning to read in Hunsrückisch, a demand of the Hunsrückisch speaking communities, we believe that it is necessary to exercise phonemic awareness, including in adults, as is done with children (Fricke \& Schäfer, 2011). This exercise may be important because there are Hunsrückisch-specific grapheme-phoneme conversion rules (cf. Altenhofen et al., 2007) and some orthographic opacity (Landerl et al., 2013; Landerl, Wimmer, \& Frith, 1997; Seymour et al., 2003) in 
Hunsrückisch spelling rules. After a short period of instruction, the awareness level can approach that of individuals who have written knowledge in the target language (cf. Chen et al., 2013). The training requires explicit exercises on the correspondence rules between phonemes and graphemes of such language.

The psycholinguistic investigation of minority languages contributes to the understanding of the diversity of multilingualism, since research predominantly contemplates majority languages, and may unveil facets of the interaction between mostly spoken dialects and languages with an established orthography.

\section{Acknowledgments}

This study was financed in part by the Coordenação de Aperfeiçoamento de Pessoal de Nível Superior - Brasil (CAPES) - Finance Code 001.

\section{References}

Abutalebi, J., Keim, R., Brambati, S. M., Tettamanti, M., Cappa, S. F., De Bleser, R., \& Perani, D. (2007). Late acquisition of literacy in a native language. Human Brain Mapping, 28(1), 19-33. doi:1002/hbm.20240

Altenhofen, C. V. (1996). Hunsrückisch in Rio Grande do Sul: Ein Beitrag zur Beschreibung einer deutschbrasilianischen Dialektvarietät im Kontakt mit dem Portugiesischen. Stuttgart: Steiner.

Altenhofen, C. V. (2010). Dachsprachenwechsel und Varietätenabgrenzung im Kontakt zwischen Hunsrückisch und Portugiesisch in Brasilien. In B. Fred (ed.). Festschrift für Harald Thun zum 60. Geburtstag (pp. 1-26). Kiel: Westensee-Verlag.

Altenhofen, C. V., Frey, J., Maria L. Käfer, Klassmann, M., Neumann, G. R., \& Spinassé, K. P. (2007). Fundamentos para a escrita do Hunsrückisch falado no Brasil. Revista Contingentia, 2(1), 73-87.

Arnqvist, A.(1992). The impact of consonant clusters on preschoolchildren's phonemic awareness: A comparison between readers and nonreaders. Scandinavian Journal of Psychology, 33(1), 29-35. doi:10.1111/j.1467-9450.1992.tb00810.x

Billig, J. D. (2014). Impacto do bilinguismo nas redes de atenção, no acesso lexical e na memória de trabalho em adultos (Ph.D. Dissertation). Federal University of Rio Grande do Sul, Porto Alegre, RS, Brazil.

Boersma, P. (2001). Praat, a system for doing phonetics by computer. Glot International, 5(9/10), 341-345.

Brown, M. C., Sibley, D. E., Washington, J. A., Rogers, T. T., Edwards, J. R., MacDonald, M. C., \& Seidenberg, M. S. (2015). Impact of dialect use on a basic component of learning to read. Frontiers in Psychology, 6(196), 1-17. doi:10.3389/ fpsyg.2015.00196

Brysbaert, M., Buchmeier, M., Conrad, M., Jacobs, A. M., Bölte, J., \& Böhl, A. (2011). The Word Frequency Effect. Experimental Psychology, 58(5), 412-424. doi:10.1027/1618-3169/a000123

Castles, A., Rastle, K., \& Nation, K. (2018). Ending the Reading Wars: Reading Acquisition From Novice to Expert. Psychological Science in the Public Interest, 19(1), 5-51. doi:10.1177/1529100618772271

Castro-Caldas, A., Miranda, P. C., Carmo, I., Reis, A., Leote, F., Ribeiro, C., \& DuclaSoares, E. (1999). Influence of learning to read and write on the morphology of 
the corpus callosum. European Journal of Neurology, 6(1), 23-28. doi:10.1046/ j.1468-1331.1999.610023.x

Castro-Caldas, A., Petersson, K. M., Reis, A., \& Stone-Elander, S. (1998). The illiterate brain. Learning to read and write during childhood influences $\mid$ nthe functional organization of the adult brain. Brain, 121, 1053-1063.

Catford, J. C. (1977). Fundamental problems in phonetics. Edinburgh: Edinburgh Univ.

Chen, S., Li, R., Li, G., Wang, Y., \& Wu, L. (2013). The effect of dialect experience on Chinese children's Mandarin phonological awareness. Reading and Writing, 26(8), 1317-1335. doi: 10.1007/s11145-012-9420-5

Dehaene, S. (2012). Os neurônios da leitura: como a ciência explica a nossa capacidade de ler. (Leonor Scliar-Cabral, Trans.). Porto Alegre: Editora Penso.

Duden. (2005). Die Grammatik: Unentbehrlich für richtiges Deutsch. Mannheim: Dudenverlag.

Durgunoğlu, A. Y., Nagy, W. E., \& Hancin-Bhatt, B. J. (1993). Cross-language transfer of phonological awareness. Journal of Educational Psychology, 85(3), 453-465. doi:10.1037/0022-0663.85.3.453

Fricke, S., \& Schäfer, B. (2011). Test für Phonologische Bewusstheitsfähigkeiten (TPB) (2. ed). Wetzlar: Schulz-Kirchner Verlag GmbH.

Frost, R., Katz, L., \& Bentin, S. (1986). Strategies for Visual Word Recognition and Orthographic Depth: a Multi-lingual Comparison. Journal of Experimental Psychology: Human Perception and Performance, 87, 243-265.

Gewehr-Borella, S. (2014). “Tu dampém fala assim?” Macroanálises pluridimensionais da variação da sonorizçaão e dessonorização das oclusivas do português de falantes bilíngues hunsriqueano-português. (Ph.D. Dissertation). Federal University of Rio Grande do Sul, Porto Alegre, RS, Brazil.

Gollan, T. H., Montoya, R., Fennema-Notestine, C., \& Morris, S. (2005). Bilingualism affects picture naming but not picture classification. Memory \& Cognition, 33(7), $1220-1234$.

Gordon, B. (1983). Lexical access and lexical decision: mechanisms of frequency sensitivity. Journal of Verbal Learning and Verbal Behavior, 22(1), 24-44. doi: 10.1016/S0022-5371(83)80004-8

Heeringa, W. (2004). Measuring dialect pronunciation differences using Levenshtein distance. (Ph.D. Dissertation). University of Groningen, Groningen, The Netherlands.

IBM Corp. (2010). Released 2010. IBM SPSS Statistics for Windows. New York: IBM Corp.

Keuleers, E., \& Brysbaert, M. (2010). Wuggy: A multilingual pseudoword generator. Behavior Research Methods, 42(3), 627-633. doi:10.3758/BRM.42.3.627

Koda, K. (2007). Reading and language learning: crosslinguistic constraints on second language reading development. Language Learning, 57(1), 1-44. doi:10.1111/ j.1467-9922.2007.00397.x

Kramer, R., \& Mota, M. B. (2015). Effects of bilingualism on inhibitory control and working memory: a study with early and late bilinguals. Gragoatá, 38, 309-331.

Landerl, K., Ramus, F., Moll, K., Lyytinen, H., Leppänen, P. H. T., Lohvansuu, K., Schulte-Körne, G. (2013). Predictors of developmental dyslexia in European orthographies with varying complexity. Journal of Child Psychology and Psychiatry, 54(6), 686-694. doi:10.1111/jcpp.12029 
Landerl, K., Wimmer, H., \& Frith, U. (1997). The impact of orthographic consistency on dyslexia: A German-English comparison. Cognition, 63(3), 315-334. doi:10.1016/S0010-0277(97)00005-X

Limberger, B. K. (2018). Processamento da leitura e suas bases neurais: um estudo sobre o hunsriqueano. (Ph.D. Dissertation). Pontifical Catholic University of Rio Grande do Sul, Porto Alegre, RS, Brazil.

Limberger, B. K., \& Buchweitz, A. (2014). The effects of bilingualism and multilingualism on executive functions. Fórum Linguístico, 11(3), 261-277. doi:10.5007/1984-8412.2014v11n3p261

Machado, L. L. (2016). Standard e substandard em contato com o português: variação na competencia de fala em Hochdeutsch de falantes de Hunsrückisch. (Master Thesis). Federal University of Rio Grande do Sul, Porto Alegre, RS, Brazil.

Machry da Silva, S. (2014). Aprendizagem fonológica e alofônica em L2: percepção e produção das vogais médias do português por falantes nativos do espanhol. (Ph.D. Dissertation). Pontifical Catholic University of Rio Grande do Sul, Porto Alegre, RS, Brazil.

Möller, R. (2011). Wann sind Kognaten erkennbar? Ähnlichkeit und synchrone Transparenz von Kognatenbeziehungen in der germanischen Interkomprehension. Linguistik Online, 46(2), 79-101.

Morais, J. (1995). A arte de ler. São Paulo: Editora UNESP.

Morais, J. (2009). Representações fonológicas na aprendizagem da leitura e na leitura competente. Textos Seleccionados. XXIV Encontro Nacional da Associação Portuguesa de Linguística, Lisbon, Portugal, pp. 7-21, 2009, Retrieved from https:// apl.pt/wp-content/uploads/2017/09/1-Morais.pdf

Morais, J., Cary, L., Alegria, J., \& Bertelson, P. (1979). Does awareness of speech as a sequence of phones arise spontaneously? Cognition, 7(4), 323-331. doi:10.1016/0010-0277(79)90020-9

Peirce, J. W. Generating stimuli for neuroscience using PsychoPy. Frontiers in Neuroinformatics, v. 2, p. 1-10, 2009.

R Core Team. (2013). R: A language and environment for statistical computing. Vienna: R Foundation for Statistical Computing. Retrieved from http://www.rproject.org/

Reis, A., \& Castro-Caldas, A. (1997). Illiteracy: a cause for biased cognitive development. Journal of the International Neuropsychological Society: JINS, 3(5), 444-450.

Reynolds, B. (1998). Phonological Awareness: Is It Language Specific? Literacy Across Cultures, 2(2), 6-10.

Sambaquy-Wallner, V. (1998). A língua alemã em São José do Hortêncio - RS. Caxias do Sul: EDUCS.

Schaumloeffel, M. A. (2003). Estudo da Interferência do Português da Variedade Dialetal Hunsrück Falada em Boa Vista do Herval. Sector de Ciências Humanas, Letras e Artes. (Master Thesis). Federal University of Paraná, Curitiba, PR, Brazil.

Schneider, M. N. (2007). As práticas sociais de professores em comunidades bilíngues alemão-português do Rio Grande do Sul. (Ph.D. Dissertation). Federal University of Rio Grande do Sul, Porto Alegre, RS, Brazil.

Scholl, A. P., \& Finger, I. (2013). Elaboração de um questionário de histórico de linguagem para pesquisas com bilíngues. Nonada Letras Em Revista, 2(21), 1-17. 
Seymour, P. H. K., Aro, M., \& Erskine, J. M. (2003). Foundation literacy acquisition in European orthographies. British Journal of Psychology, 94(2), 143-174. doi:10.1348/000712603321661859

Sullivan, M., Poarch, G., \& Bialystok, E. (2017). Why is lexical retrieval slower for bilinguals? Evidence from picture naming. Bilingualism: Language and Cognition, 21(3), 479-488. doi:10.1017/S1366728917000694

Wiesemann, U. (2008). Contribuição ao desenvolvimento de uma ortografia da língua Hunsrik falada na América do Sul. Associação Internacional de Lingüística-SIL. Cuiabá, MT, Brazil. Retrieved from https://www.sil.org/resources/publications/ entry/17006

Ziegler, J. C., \& Goswami, U. (2005). Reading acquisition, developmental dyslexia, and skilled reading across languages: A Psycholinguistic Grain Size Theory. Psychological Bulletin, 131(1), 3-29. doi:10.1037/0033-2909.131.1.3

Recebido em: 09/03/2019

Aceito em: 30/07/2019 


\section{APPENDIX}

\section{Cognates}

Phoneme synthesis test

\begin{tabular}{|c|c|c|}
\hline $\begin{array}{l}\text { Auditory } \\
\text { stimuli }\end{array}$ & $\begin{array}{l}\text { Written } \\
\text { stimuli }\end{array}$ & $\begin{array}{l}\text { Hunsrückisch } \\
\text { words }\end{array}$ \\
\hline [hurt] & Hut & [hułd] \\
\hline$[10 x]$ & Loch & {$[10 x]$} \\
\hline [fułs] & Fuß & [futs] \\
\hline [glałs] & Glas & [g̊lo:s] \\
\hline [hant] & Hand & [hand] \\
\hline [mo:nt] & Mond & [mo:nd] \\
\hline [ $\int$ tain $]$ & Stein & [ [de:n] \\
\hline [hevets] & Herz & [heds] \\
\hline ['flayə] & Schlange & [Slay] \\
\hline ['naxba:e्n] & Nachbar & ['noxbe] \\
\hline ['Jveste] & Schwester & 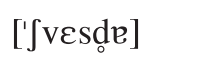 \\
\hline ['fenste] & Fenster & ['fensdede] \\
\hline
\end{tabular}

\section{Syllable onset manipulation test}

\begin{tabular}{|c|c|c|}
\hline $\begin{array}{l}\text { Auditory } \\
\text { stimuli }\end{array}$ & $\begin{array}{l}\text { Written } \\
\text { stimuli }\end{array}$ & $\begin{array}{l}\text { Hunsrückisch } \\
\text { words }\end{array}$ \\
\hline ['jakə] & Jacke & ['jagə] \\
\hline [vint] & Wind & [vind] \\
\hline []tat $]$ & Stadt & [ $\left[\mathrm{tad}_{0}\right]$ \\
\hline [golt] & Gold & [gold] \\
\hline ['aime] & Eimer & ['e:me] \\
\hline ['flafə] & Flasche & [flaf] \\
\hline ['bo:nən] & Bohnen & ['bo:nə] \\
\hline [pa'pie] ] & Papier & [ba'baie] \\
\hline ['brunən] & Brunnen & ['borunə] \\
\hline ['Jtra:sə] & Straße & [ $\left.\int \mathrm{dro}: \mathrm{s}\right]$ \\
\hline [ma'fi:nə] & Maschine & [ma'fi:n] \\
\hline ['daưmən] & Daumen & [do'vmə] \\
\hline
\end{tabular}

\section{Hunsrückisch}

Phoneme synthesis test

\begin{tabular}{|c|c|c|c|c|c|}
\hline $\begin{array}{l}\text { Auditory } \\
\text { stimuli }\end{array}$ & $\begin{array}{l}\text { Written } \\
\text { stimuli }\end{array}$ & $\begin{array}{l}\text { German } \\
\text { words }\end{array}$ & $\begin{array}{l}\text { Auditory } \\
\text { stimuli }\end{array}$ & $\begin{array}{l}\text { Written } \\
\text { stimuli }\end{array}$ & $\begin{array}{l}\text { Hunsrückisch } \\
\text { words }\end{array}$ \\
\hline [ $\left[\int e: a\right]$ & Schea & ['Je:rə] & [g̊cdł] & Gedl & ['gyrtəl] \\
\hline [mo:do d] & Mood & [ma:kt] & [vofd] & Woscht & [vorst] \\
\hline$\left[\mathrm{p}^{\mathrm{h}} \varepsilon \int\right]$ & Pesch & ['pfırzıç] & [g̊nıg̊] & Gnick & [knık] \\
\hline ['mo:xə] & Mooche & ['ma:gən] & [ $\left.\int \varepsilon \mathrm{ds}\right]$ & Schetz & [ Y Yrtsə] \\
\hline [jlob] & Schlob & ['Jlaifə] & ['k $\left.\mathrm{K}^{\mathrm{h}} \mathrm{d}: \mathrm{d} ə\right]$ & Goode & [gartən] \\
\hline$\left[\mathrm{b} \varepsilon \int \mathrm{d}_{0}\right]$ & Bescht & ['byrstə] & ['o:mats] & Omats & ['a:maizə] \\
\hline$\left[f \varepsilon: p \int d\right]$ & Feascht & ['ferzə] & ['bırbça] & Pipche & ['kykən] \\
\hline ['borırıç] & Berrich & [berk] & ['sarıç] & Sarig & [zark] \\
\hline ['k & Kooreb & [korp] & [dọsug̊rə] & Zuckre & ['tsukrro:e] \\
\hline nintsjje] & Mintsje & ['ketsçən] & ['Jbøesja] & Spesje & ['vitsçən] \\
\hline 10rəs] & Schnores & ['Snueba:et] & ['Jme:dss ] & Schmedse & ['Jmarsmykə] \\
\hline derıg̊] & Sterig & ['Jtzrkeme:1] & ['hing̊əł] & Hinkel & [hu:n] \\
\hline
\end{tabular}




\section{Pseudowords}

\begin{tabular}{|c|c|c|c|}
\hline \multicolumn{2}{|c|}{ Phoneme synthesis test } & \multicolumn{2}{|c|}{ Syllable onset manipulation test } \\
\hline $\begin{array}{l}\text { Auditory } \\
\text { stimuli }\end{array}$ & $\begin{array}{l}\text { Written } \\
\text { stimuli }\end{array}$ & $\begin{array}{l}\text { Auditory } \\
\text { stimuli }\end{array}$ & $\begin{array}{l}\text { Written } \\
\text { stimuli }\end{array}$ \\
\hline [vo:t] & Woht & [vims] & Wims \\
\hline$\left[\mathrm{v} \varepsilon \int\right]$ & Wesch & ['dine] & Diner \\
\hline [med] & Met/Med & [hekt] & Hekt \\
\hline [pfas] & Pfas & [lemd] & Lemd \\
\hline [hats] & Hatz & [ $[$ tamp] & Stamb \\
\hline [ [ nob $]$ & Schnob & ['fวl]ə] & Folsche \\
\hline [kвorn] & Kreun & ['mabıç] & Mabich \\
\hline ['meviç] & Mewich & [g̊ra:g̊s] & Kraks \\
\hline ['bo::əəd] & Boored & ['nəImən] & Neumen \\
\hline ['daxlae] & Dachlar & ['kinzəl] & Kinsel \\
\hline []no'bar] & Schnobei & ['Smeklə] & Schmekle \\
\hline ['Jmediç] & Schmedich & ['blıçja] & Bloche \\
\hline
\end{tabular}

